\title{
Dynamic Establishment of Weight of Enterprise's Internal Function Based on AHP and QFD
}

\author{
Pei HE, Yue-Xiong GONG, Li-Xing ZHANG, Li XIE
}

China Tobacco Zhejiang Industrial Company Limited, Hangzhou, 310024, China

\begin{abstract}
Modern enterprise management strives to become effective and pragmatic, usually, KPI is the most essential key indicator for the enterprise examination department. However, because the supporting and bearing roles of KPI for different departments are different, no a rather scientific quantification for the weight between them is available, unbalanced examination weights between indicators and departments usually exists. Here, it is with balanced score card to breakdown enterprise's key tasks, card the performance indicators supporting enterprise's key tasks, and utilize AHP and QFD method to dynamically establish a standard for measuring each department's indicators so as to provide a basis for enterprise's scientific examination.
\end{abstract}

\section{Integral Frame of the Project}

Here, with the strategy of Hangzhou Cigarettes Factory as a start point, the key performance indicators of current year on basis of enterprise's tasks of the said year are carded, the broken-down indicators are sorted with KJ method, and the weight of the key indicators are determined with AHP method. Comparison with industry advanced level is made with key indicators-functional department matrix, and finally the weight supporting each department's key indicator is obtained. The integral frame is shown in Fig. 1.

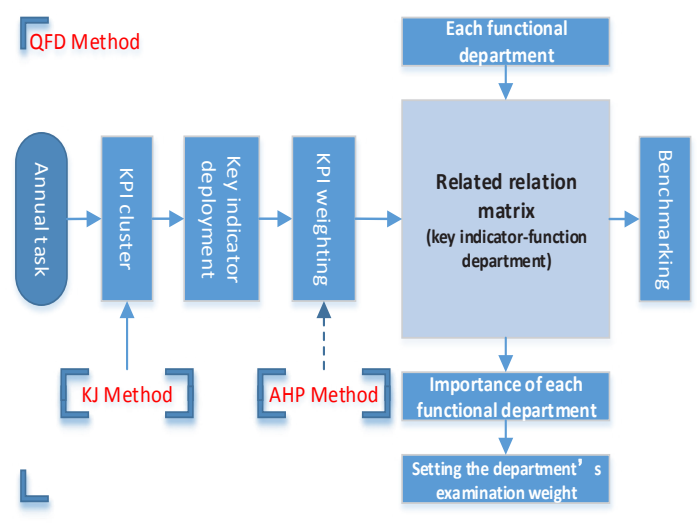

Fig. 1 Diagram of Integral Study Frame

\section{Breaking Down of Annual Key Performance Indicators}

Some enterprise's annual tasks are rather definite, while some tasks are hidden in the high-level documents or laws or regulations of external origins, usually, the enterprise conducts an overall carding to ensure comprehensiveness of its annual tasks. Generally, an enterprise may be carded from four aspects (finance, customers, internal operation, and learning and growth) of the balanced score card. After breaking down of tasks, each supporting key indicator is re-divided. Taking the carding of year-2015 key performance indicators of Hangzhou Cigarettes Factory as example, the carding of Hangzhou Cigarettes Factory in 2015 in four aspects determines the annual tasks, as shown in Table 1.

Tab. 1 Breaking Down Table of Key Performance Indicators of Hangzhou Cigarettes Factory in 2015

\begin{tabular}{|l|l|l|}
\hline $\begin{array}{l}\text { Level-I } \\
\text { indicators }\end{array}$ & $\begin{array}{l}\text { Level-II } \\
\text { indicators } \\
\text { (Balanced } \\
\text { Score } \\
\text { Card) }\end{array}$ & $\begin{array}{l}\text { Level-III performance } \\
\text { indicators }\end{array}$ \\
\hline & Finance & $\begin{array}{l}\text { Controllable management fee } \\
\text { of a single box }\end{array}$ \\
\hline
\end{tabular}




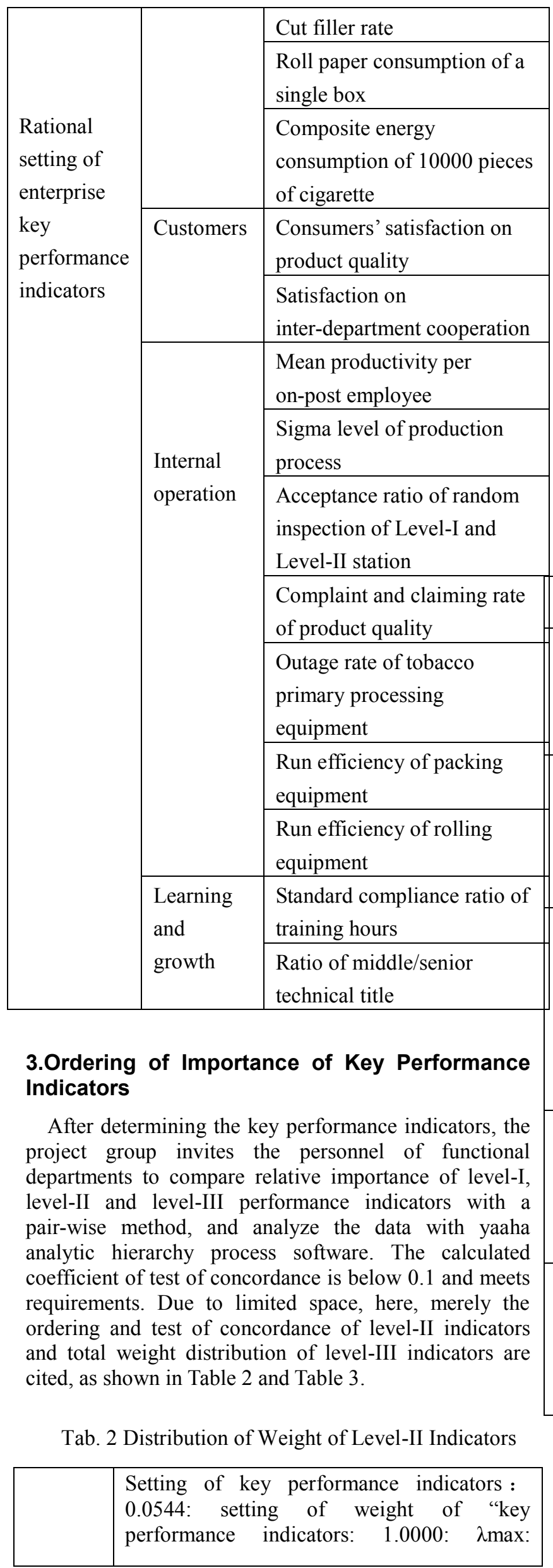

\begin{tabular}{|l|l|l|l|l|l|}
\hline \multirow{2}{*}{} & \multicolumn{3}{|l|}{4.1454} & \multicolumn{4}{|l|}{} \\
\cline { 2 - 6 } & $\begin{array}{l}\text { Finan } \\
\text { ce }\end{array}$ & $\begin{array}{l}\text { Interna } \\
1 \\
\text { operati } \\
\text { on }\end{array}$ & $\begin{array}{l}\text { Learni } \\
\text { ng and } \\
\text { growth }\end{array}$ & $\begin{array}{l}\text { Custom } \\
\text { ers }\end{array}$ & wi \\
\hline $\begin{array}{l}\text { Finance } \\
1.000 \\
0\end{array}$ & 0.5000 & 4.0000 & 0.3333 & $\begin{array}{l}0.19 \\
03\end{array}$ \\
\hline $\begin{array}{l}\text { Internal } \\
\text { operatio } \\
\text { n }\end{array}$ & $\begin{array}{l}2.000 \\
0\end{array}$ & 1.0000 & 4.0000 & 0.5000 & 0.28 \\
36 \\
\hline $\begin{array}{l}\text { Learnin } \\
\text { g and } \\
\text { growth }\end{array}$ & 0.250 & 0.2500 & 1.0000 & 0.2500 & $\begin{array}{l}0.07 \\
59\end{array}$ \\
\hline $\begin{array}{l}\text { Custom } \\
\text { ers }\end{array}$ & $\begin{array}{l}3.000 \\
0\end{array}$ & 2.0000 & 4.0000 & 1.0000 & 0.45 \\
0
\end{tabular}

Tab. 3 Distribution of Weight of Level-III Indicators

\begin{tabular}{|c|c|c|c|c|c|}
\hline cheme & $\begin{array}{l}\text { We } \\
\text { ight }\end{array}$ & Scheme & $\begin{array}{l}\text { Wei } \\
\text { ght }\end{array}$ & Scheme & $\begin{array}{l}\text { Weig } \\
\text { ht }\end{array}$ \\
\hline $\begin{array}{l}\text { Consumers' } \\
\text { atisfaction } \\
\text { n product } \\
\text { quality }\end{array}$ & $\begin{array}{l}0.4 \\
052\end{array}$ & $\begin{array}{l}\text { Mean } \\
\text { productivit } \\
\text { y per } \\
\text { on-post } \\
\text { employee }\end{array}$ & $\begin{array}{l}0.02 \\
11\end{array}$ & $\begin{array}{l}\text { Run } \\
\text { efficiency } \\
\text { of rolling } \\
\text { equipmen } \\
t\end{array}$ & $\begin{array}{l}0.02 \\
97\end{array}$ \\
\hline $\begin{array}{l}\text { Composite } \\
\text { anergy } \\
\text { onsumption } \\
\text { f } 10000 \\
\text { ieces of } \\
\text { igarette }\end{array}$ & $\begin{array}{l}0.0 \\
432\end{array}$ & $\begin{array}{l}\text { Sigma } \\
\text { level of } \\
\text { production } \\
\text { process }\end{array}$ & $\begin{array}{l}0.02 \\
82\end{array}$ & $\begin{array}{l}\text { Run } \\
\text { efficiency } \\
\text { of } \\
\text { packing } \\
\text { equipmen } \\
\mathrm{t}\end{array}$ & $\begin{array}{l}0.03 \\
35\end{array}$ \\
\hline $\begin{array}{l}\text { Roll paper } \\
\text { onsumption } \\
\text { f a single } \\
\text { ox }\end{array}$ & $\begin{array}{l}0.0 \\
233\end{array}$ & $\begin{array}{l}\text { Acceptanc } \\
\text { e ratio of } \\
\text { random } \\
\text { inspection } \\
\text { of Level-I } \\
\text { and } \\
\text { Level-II } \\
\text { station }\end{array}$ & $\begin{array}{l}0.06 \\
13\end{array}$ & $\begin{array}{l}\text { Standard } \\
\text { complian } \\
\text { ce ratio of } \\
\text { training } \\
\text { hours }\end{array}$ & $\begin{array}{l}0.03 \\
79\end{array}$ \\
\hline $\begin{array}{l}\text { Cut filler } \\
\text { ate }\end{array}$ & $\begin{array}{l}0.0 \\
805\end{array}$ & $\begin{array}{l}\text { Complaint } \\
\text { and } \\
\text { claiming } \\
\text { rate of } \\
\text { product } \\
\text { quality }\end{array}$ & $\begin{array}{l}0.08 \\
42\end{array}$ & $\begin{array}{l}\text { Ratio of } \\
\text { middle/se } \\
\text { nior } \\
\text { technical } \\
\text { title }\end{array}$ & $\begin{array}{l}0.03 \\
79\end{array}$ \\
\hline $\begin{array}{l}\text { Controllable } \\
\text { nanagement } \\
\text { ee of a } \\
\text { ingle box }\end{array}$ & $\begin{array}{l}0.0 \\
432\end{array}$ & $\begin{array}{l}\text { Outage } \\
\text { rate of } \\
\text { tobacco } \\
\text { primary } \\
\text { processing } \\
\text { equipment }\end{array}$ & $\begin{array}{l}0.02 \\
56\end{array}$ & $\begin{array}{l}\text { Satisfacti } \\
\text { on on } \\
\text { inter-depa } \\
\text { rtment } \\
\text { cooperati } \\
\text { on }\end{array}$ & $\begin{array}{l}0.04 \\
50\end{array}$ \\
\hline
\end{tabular}

4.Building of House of Quality of Key Performance Indicators-functional Department

Competitive Assessment of Key Performance Indicators 
In order to find out the difference between indicators of us and other benchmarking enterprises, our indicators are compared with other enterprise's indicators in five grades (score 1-5) on basis of data on the excellence and standard-compliance of year-2015 cigarette industry, and in combination with features (highlights) of our key performance indicators, their absolute importance is obtained, as shown in Fig. 2.

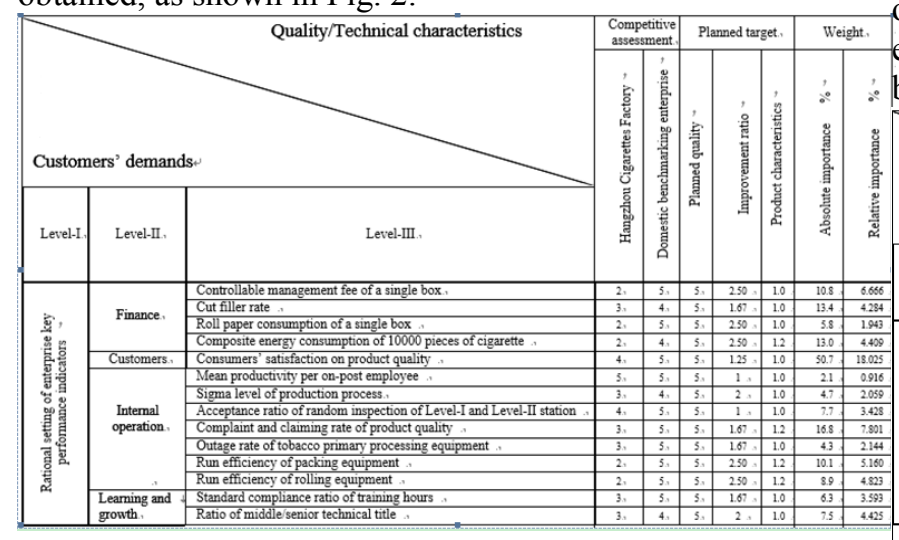

Fig. 2 Competitive Assessment Table of Key Performance Indicators

\section{Matrix Analysis of Key Technical Indicators-functional Department Relation}

After completion of the fore-phase work, the project group determines the matrix of "key performance indicators-each department's function" two-dimensional relation matrix, which is used to express the complex relation between each key performance indicator item and each functional department. Here, figure 6 expresses the "Strong" relation, i.e. the improvement of a key performance is strongly related with the compliance of corresponding functional department; 3 expresses "medium" relation, i.e. the improvement of a key performance is medium related with the compliance of corresponding functional department; 1 expresses the "weak" relation, i.e. the improvement of a key performance is weakly related with the compliance of corresponding functional department; and the blank expresses the no direct relation. When the selected product performance indicators are closely related with the compliance of corresponding functional department, for embodying the correlation, figure 9 is used, as shown in Table 3.

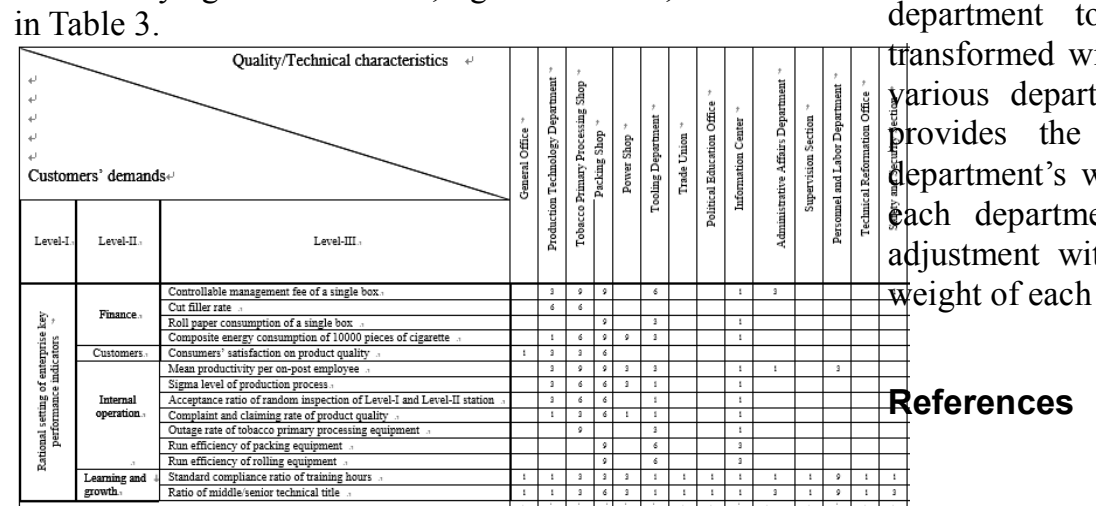

Fig. 3 Matrix Analysis of Key Performance
Indicators-Functional Department Relation

\section{Building of House of Quality for Key Performance Indicators and Functional Departments}

As per the principle and structure of the house of quality, roof structure should exist, however, which is omitted, as shown in Fig. 4, since the relation between enterprise's functional departments is positive, instead of being negative.

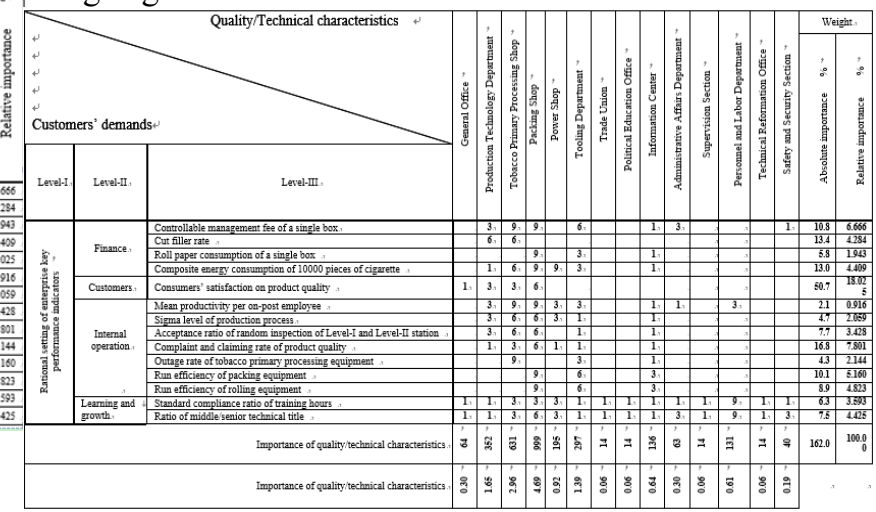

Fig. 4 House of Quality for Key Performance Indicators and Functional Departments

From the above-mentioned analysis of house of quality, we concluded that if type I department is scored above 600, type II department is scored 100-599, and type III department is scored below 99, the Packing Shop and Tobacco Primary Processing Shop are type I department, the Tooling Department, Production and Technology Department, Power Shop, Information Center, and Personnel and Labor Department are type II department, and the General Office, Trade Union, Political Education Office, Supervision Section, Technical Reformation Office, and Safety And Security Section are type III department.

\section{Conclusion}

The enterprise's work tasks of current year are carded from its strategy, the key performance indicators of the current year are broken down through comprehensive consideration with balanced score card mode, the supporting and contribution of each functional department to the key performance indicators is transformed with QFD method, and finally the types of yarious departments are scientifically decided, which provides the support to examine each enterprise department's weight and the objective data basis to set each department's basic wage and bonus. Dynamic adjustment with this method will dynamically set the weight of each department's function. 
[1] Xiong Wei, Quality Innovation-QFD-Based System Method [M]. China Zhijian Publishing House, 2015: 47-89

[2] Xiong Wei, Quality-Function-Development [M]. Beijing: Chemical Industry Press, 2005: 43-95

[3] Chen Honggen, Liang Gongqian Quality Assurance Model of QFD-based Postgraduate Culture [J]. Academic Degrees and Graduate Education, 2007 (2): 14- 1 [6]

[4] Sun Yuanyuan, Liu Fei, Li Li, Determination of Attribute Final Importance for Personalized Product Development Using Kano Model and QFD Integration Method [J]. Computer Integrated Manufacturing Systems, 2014, 20 (11): 2697-2703

[5] Jin Gang, Li Ming, Analysis and Research of Customer's Requirement Based on Quality Function Configuration, [J]. Manufacturing Technology \& Machine Tool, 2009 (8): 116 -126

[6] Wang Shuang, Yin Guofu, He Zhongxiu, Research on Customer Requirements' Target System Based on Kano Model [J] Packaging Engineering, 2006, 27 (4): 209-213 